\title{
STATUS KEPEMILIKAN TANAH PADA KAWASAN PANTAI DI PESISIR KOTA BANDAR LAMPUNG
}

\author{
Sudirman Mechsan
}

Dosen Bagian Hukum Administrasi Negara FH Universitas Lampung

Abstrak

Ketidaktahuan masyarakat atas Undang-Undang Nomor 5 Tahun 1960 tentang Peraturan Dasar Pokok-Pokok Agraria dan Undang-Undang Nomor 27 Tahun 2007 tentang Pengelolaan Wilayah Pesisir dan Pulau-pulau Kecil membawa konsekuensi pemilikan tanah yang tidak berdasar dan pemanfaataan tanah yang merusak lingkungan. Ruang kawasan pantai merupakan ruang wilayah diantara daratan dengan ruang lautan yang saling berbatasan. Berdasarkan kemampuan daya dukung (carrying capacity) dan kemampuan alamiah untuk memperbaharui (assimilative capacity), serta kesesuaian penggunaannya, kawasan pantai dan hutan mangrove menjadi sasaran atas kegiatan eksploitasi sumberdaya alam dan pencemaran lingkungan akibat tuntutan pembangunan yang masih cendrung lebih menitik beratkan bidang ekonomi. Semakin banyak manfaat/keuntungan ekonomis diperoleh, maka semakin berat pula beban kerusakan lingkungan/ekologis yang ditimbulkannya. Begitu pula sebaliknya, bila semakin sedikit manfaat/keuntungan ekonomis, semakin ringan pula kerusakan lingkungan yang ditimbulkannya.

Kata Kunci: Status pemilikan tanah, pemanfaatan tanah, wilayah pesisir.

\section{PENDAHULUAN.}

Negara Kesatuan Republik Indonesia sebagai suatu Negara kepulauan terdiri dari 17.508 buah pulau besar dan kecil yang secara keseluruhan memiliki panjang garis pantai sekitar $81.000 \mathrm{Km}$, merupakan karunia Tuhan Yang Maha Esa kepada bangsa Indonesia. Sejarah demografi suku-suku dan penyebaran penduduk di pesisir pantai Indonesia merupakan kronologi awal pengelolaan dan penguasaan tanah pada kawasan itu. Secara turun temurun masyarakat pantai menguasai tanah, baik penguasaan secara perorangan maupun adat.

Pada waktu Indonesia di jajah Belanda, pemerintahan di Indonesia dipegang oleh pemerintah Kolonial
Hindia Belanda. Hukum pertanahan yang berlaku di Indonesia pada waktu itu bersifat Dualisme yaitu berlaku dua hukum secara bersamaan dan ditempat yang sama. Hukum pertanahan yang berlaku pada saat itu adalah Hukum pertanahan Adat untuk kelompok pribumi dan hukum pertanahan Barat untuk orang Eropa.

Pemerintah Kolonial Belanda pada saat menjajah di Indonesia Kebijakan di bidang pertanahan mempunyai konsep Tanah dimiliki Negara, artinya Negara sebagai pemilik tanah dengan segala konsekuensinya. Kebijakan ini dikenal dengan nama Domein Verklaring. Dengan kebijakan tersebut pemerintah kolonial Belanda hanya meminta alat bukti kepemilikan tanah kepada warga 
pribumi yang merasa memiliki tanah. Apabila warga pribumi tidak bisa menunjukkan alat bukti kepemilikan tanah berupa sertipikat maka tanah tersebut menjadi milik pemerintah kolonial Belanda.

Dengan kebijakan tersebut maka semua kepemilikan tanah pada masa pemerintahan kolonial Belanda di bumi Indonesia ada pada pemerintahan tersebut, dalam pengertian pemerintah kolonial dapat memberikan hak milik kepada orang asing untuk mendapatkan tanah dengan hak milik, atau pada pemerintahan kolonial disebut hak Eigendom.

Pada masa pemerintahan kolonial Belanda bumi Indonesia ini banyak dikuasai orang asing baik dengan hak milik (eigendom) atau hak sewa sehingga bertambahlah penderitaan rakyat Indonesia karena tanah yang diambil oleh pemerintah Hindia Belanda dijual atau disewakan kepada orang asing.

Sejak Indonesia merdeka 17 Agustus 1945 pendiri bangsa ini telah memikirkan pengelolaan Negara terutama tentang kepemilikan tanah, maka pemerintah bersama DPR menerbitkan Undang-Undang Nomor. 5 Tahun 1960 tentang Peraturan Dasar Pokok-Pokok Agraria. Di dalam Undang Undang tersebut langkah pertama yang dilakukan adalah Reforma Struktura yaitu mereformasi semua aturan dari pemerintah Kolonial Belanda yang menyengsarakan rakyat Indonesia dengan cara memutuskan mencabut semua aturan-aturan pemerintah Belanda yang berkaitan dengan tanah.

Selanjutanya menggantinya dengan kebijakan bahwa konsep tanah dikuasai oleh Negara Pasal 33 ayat (3) UUD 1945 jo Pasal 2 ayat
(1) UU No. 5 Tahun 1960, tujuannya adalah untuk mensejahterakan rakyat dan bangsa Indonesia. Orang asing tidak diberi tempat untuk mendapatkan hak milik atas tanah di bumi Indonesia ini, untuk orang asing hanya diperbolehkan dengan hak pakai saja dengan batas waktu tertentu.

Namun menurut pengamatan penulis masih banyak penduduk bahkan orang asing menguasai tanah dikawasan pantai bahkan pulaupulau di bumi Indonesia ini dengan berbagai modus penyelundupan hukum \{Radar Lampung Senin 24 Mei 2010, Tiga WNA Miliki Hektaran Lahan).

Berdasarkan uraian tersebut permasalahan yang diangkat adalah Bagaimana status kepemilikan Tanah pada kawasan pantai di pesisir Kota Bandar Lampung, dan Apakah orang asing dapat mempunyai Hak Milik di Negara Republik Indonesia?

\section{METODE PENELITIAN.}

Penelitian ini menggunakan pendekatan normative dan empiris. Pendekatan normative dimaksudkan bahwa pendekatan ini melihat hukum sebagai suatu sistem peraturanperaturan yang abstark, dan sebagai subyek yang berdiri sendiri atau lembaga otonom yang terlepas dari kaitan-kaitannya dengan hal-hal di luar peraturan-peraturan tersebut. Pendekatan empiris dimaksudkan untuk melihat perilaku anggota masyarakat dalam hubungannya hidup bermasyarakat, baik perbuatan yang seharusnya dipatuhi, atau bersifat perintah maupun larangan. Data sekunder dan data primer merupakan data utama yang dijadikan sumber kajian. Data 
sekunder akan diperoleh dari bahan hukum primer dan sekunder. Bahan hukum primer berupa perundangundangan, hukum kebiasaan dan yurisprudensi. Bahan hukum sekunder berupa bahan kepustakaan seperti buku-buku, jurnal dan hasil kegiatan ilmiah seperti laporan penelitian, seminar, lokakarya dan diskusi - diskusi. Data primer diperoleh dari informan dengan cara wawancara dengan bantuan daftar pertanyaan yang telah disiapkan sebelumnya. Analisis data dilakukan dengan metode diskriptif kualitatif.

\section{PEMBAHASAN}

\subsection{Tanah di kuasai Negara}

Pada masa pemerintahan
kolonial Belanda di Indonesia,
hukum agraria yang berlaku adalah
hukum kolonial Belanda yang diatur
dalam Undang Undang Agraisch No.
55. Untuk melaksanakan ketentuan-
ketentuan di dalam Undang Undang
Agrarisch 1870 itu maka diadakan
peraturan pelaksanaannya yang
disebut Keputusan Agraria (Agrarisch Besluit), yang dimuat di dalam Staats Blad 1870 No. 118, yang terpenting keputusan agrarian itu adalah Pasal 1 yang pada pokoknya menyatakan bahwa semua tanah yang tidak dapat dibuktikan oleh orang lain bahwa di atasnya ada hak eigendom adalah milik (domein) Negara. Pernyataan yang terjelma pada Pasal 1 terkenal dengan istilah asing "domein verklaring" Pada waktu itu pemerintah Kolonial Belanda memandang bahwa seluruh raja-raja di Indonesia telah tunduk kepada kerajaan Belanda maka seluruh tanah yang terdapat di bumi Indonesia adalah "Milik" kerajaan Belanda. Konsekuensi dari Negara sebagai pemilik maka negara mempunyai wewenang yang luas terhadap miliknya tersebut,sebagai contoh adalah Negara dapat menjual tanah kepada orang asing., sehingga orang asing dimungkinkan mempunyai hak milik di Indonesia pada pemerintah kolonial Belanda . Pada prinsipnya asas agrarian pemerintah kolonial Belanda Negara sebagai pemilik sangatlah tidak cocok. Alasannya adalah jauh hari pendiri Negara ini telah sepakat melalui Pasal 33 ayat (3) UUD 1945 bahwa bumi, air serta kekayaan alam yang terkandung di dalamnya dikuasai oleh Negara. Selain itu asas agraria Negara sebagai pemilik sangat bertentangan dengan kehidupan masyarakat Indonesia, yang terbiasa dengan hak ulayat pada masyarakat adatnya. Dan yang terakhir menurut pengalaman sejarah bahwa Negara sebagai pemilik sangat mensengsarakan rakyat dan akan menghilangkan hakhak rakyat.

\subsection{Pengertian di Kuasai Negara.}

Berbeda setelah Indonesia merdeka, Undang Undang Pokok Agraria Nomor. 5 Tahun 1960 tentang Peraturan Dasar PokokPokok Agraria dibentuk tanpa perlu mengambil alih politik hukum agrarian Belanda. UUPA menghapuskan Domeinverklaring dengan maksud karena tidak sesuai filosofi dan pandangan hidup dari Negara Republik Indonesia. Dalam mengadakan hubungan langsung antara Negara dengan tanah, hak Negara adalah hak menguasai atau tanah di bumi Republik ini di kuasai oleh Negara sesuai Pasal 33 ayat (3) UUD 1945. Pengertian dikuasai itu bukan berarti dimiliki, tetapi Negara sebagai organisasi kekuasaan diberi wewenang seperti yang diatur dalam 
Pasal 2 ayat (2) UU Nomor 5 Tahun 1960 untuk:

a. mengatur dan menyelenggarakan peruntukkan, penggunaan, persediaan dan pemeliharaan bumi, air dan ruang kasa serta kekayaan alam tersebut.

b. Menentukan dan mengatur hubungan-hubungan hukum antara orang-orang dengan bumi, air, ruang angkasa serta kekayaan alam yang terkandung di dalamnya.

c. Menentukan dan mengatur hubungan-hubungan hukum antara orang-orang dan perbuatan-perbuatan hukum yang mengenai bumi, air, dan ruang angkasa serta kekayaan alam yang terkandung di dalamnya.

Mengatur dimaksud dalam Pasal 2 ayat (2) adalah membuat peraturan kemudian menyelenggarakannya artinya melaksanakannya (exsekution) atas peruntukan (use), persediaan (reservation) dan pemeliharaannya (maintenance). (A.P Parlindungan, 1993). Juga untuk menentukan dan mengatur (menetapkan dan membuat peraturan-peraturan) bagaimana seharus-nya hubungan antara orang atau Badan Hukum dengan bumi, air, ruang angkasa dan kekayaan alam yang terkandung di dalamnya. Selain itu hak menguasai Negara tersebut dimungkinkan organisasi kekuasaan itu untuk :

a. Memberikan hak-hak keperdataan baik kepada perseorangan ataupun badanbadan hukum privat seperti Hak Milik, Hak Guna Usaha, Hak Guna Banguan dan Hak Pakai;

b. Mengakui suatu hukum politik yang sudah ada sebelumnya, seperti Hak Ulayat masyarakat hukum adat (Pasal 3 UUPA);

c. Memberikan hukum public yang baru yaitu Hak Pengelolaan yang diberikan kepada lembagalembaga pemerintahan ataupun perusahaan-perusahaan negara/daerah.

d. Dapat diberikan Hak Pakai (khusus) yaitu Hak Pakai yang tidak terbatas waktunya dan diberikan untuk pelaksanaan tugasnya seperti Hak Pakai untuk perwakilan-perwakilan Negara asing untuk kepentingan lembaga pemerintahan.

Beranjak dari uraian di atas maka tanah-tanah yang ada di wilayah Republik Indonensia ini dapat dikategorikan sebagai berikut:

1. Tanah yang dikuasai langsung oleh Negara (pada umumnya ini disingkat saja dengant anah Negara) atau tanah bebas yaitu tanah yang tidak ada haknya (tanah yang tidak termasuk kelompok a; b; c dan d).

2. Tanah Negara tidak bebas, yaitu tanah Negara yang wewenangnya telah dilimpahkan (termasuk kelompok b dan c).

3. Tanah Negara yang dibebani hak, yaitu tanah Hak Milik; Hak Guna Usaha; Hak Guna Bangunan; dan Hak Pakai, hak ini pada perseorangan, dan badan hukum. (termasuk kelompok a dan b ) (AP. Parlindungan, 1993)

\subsection{Hanya Warga Negara Indonesia yang diberikan Hak Milik}

Dasar kenasionalan hukum agrarian diletakakn dalam Pasal 1 ayat (1), yang menyatakan, bahwa : "Seluruh wilayah Indonesia adalah kesatuan tanah-air dari seluruh rakyat 
Indonesia, yang bersatu sebagai bangsa Indonesia" dan Pasal 1 ayat (2) yang berbunyi bahwa :Seluruh bumi, air dan rung angkasa, termasuk kekayaan alam yang terkandung di dalamnya dalam wilayah Republik Indonesia sebagai karunia Tuhan Yang Maha Esa, adalah bumi, air dan ruang angkasa bangsa Indonesia dan merupakan kekayaan nasional". Ini berarti bahwa bumi, air dan ruang angkasa dalam wilayah Republik Indonesia yang kemerdekaannya diperjuangkan oleh bangsa sebagai keseluruhan, menjadi hak pula dari bangsa Indonesia, jadi tidak sematamata menjadi hak dan dari para pemiliknya saja. Demikian pula tanah-tanah di daerah-daerah dan pulau-pulau yang bersangkutan saja. Dengan pengertian demikian maka hubungan bangsa Indonesia dengan bumi, air dan ruang angkasa Indonesia merupakan semacam hubungan hak ulayat yang diangkat pada tingkatan yang paling atas, yaitu pada tingkatan yang mengenai seluruh wilayah Negara. Adapun hubungan antara bangsa dan bumi, air serta ruang angkasa Indonesia itu adalah hubungan yang bersifat abadi Pasal 1 ayat (3) . Ini berarti bahwa selama rakyat Indonesia yang bersatu sebagai bangsa Indonesia amsih ada pula, dalam keadaan yang bagaimanapun tidak ada sesuatu kekuasaan yang akan dapat memutuskan meniadakan hubungan tersebut. Di dalam hukum agraria nasional dikenal pula hak milik yang dapat dihaki oleh seseorang baik sendiri maupun bersama-sama dengan orang-orang lain atas bagian dari bumi Indonesia (Pasal 4 jo Pasal 20).

Hak Milik adalah hak turuntemurun, terkuat dan terpenuh yang dapat dipunyai orang atas tanah dengan mengingat fungsi sosial. Turun menurun menunjukkan bahwa hak tersebut dapat berlangsung terus selama pemilik masih hidup dan jika meninggal dunia hak tersebut dapat dilanjutkan oleh ahli warisnya. Terkuat menunjukkan bahwa kedudukan hak itu paling kuat, jika dibandingkan dengan hak-hak atas tanah lainnya karena terdaftar dan pemilik hak diberi tanda bukti hak (sertifikat), sehingga mudah dipertahankan terhadap pihak lain. Disamping itu, jangka waktu pemilikannya tidak terbatas. Yerpenuh menunjukkan bahwa hak itu memberikan kepada pemiliknya wewenang paling luas, jika disbanding-kan dengan hak-hak atas tanah lainnya, tidak berinduk pada hak ats tanah lain, dan peruntukkannya tidak terbatas selama tidak ada pembatasan dari penguasa. Ini menunjukkan bahwa hak milik mempunyai fingsi sosial .Sifat-sifat seperti ini tidak ada pada hak-hak atas tanah lainnya.

Menurut ketentuan Pasal 21 ayat (1) UUPA hanya warga Negara Indonesia yang dapat mempunyai hak milik atas tanah. Hak milik kepada orang asing dilarang (Pasal 26 ayat (2)). Orang-orang asing dapat mempunyai tanah dengan hak pakai yang luasnya terbatas.

\subsection{Status Fungsi dan Kepemilikan Lahan Pantai}

Sejarah demografi suku-suku dan penyebaran penduduk di pesisir pantai Indonesia merupakan kronologis awal pengelolaan dan penguasaan lahan kawasan itu. Secara turun-temurun masyarakat pantai menguasai lahan, baik penguasaan secara perorangan maupun adat. Sejak tahun 1982, 
sebagaian daratan kawasan pantai dan hutan-hutan mangrove telah ditetapkan fungsi peruntukkannya dalam Tata Guna Hutan Kesepakatan (TGHK). Berdasarkan TGHK tersebut, pembagian fungsi hutan meliputi : hutan produksi terbatas, hutan produksi biasa, hutan produksi yang dapat dikonversi dan areal peruntukkan lainnya.

Pengelolaan kawasan budidaya pantai tidak dapat dipisahkan dari status fungsi dan kepemilikan lahan pada kawasan tersebut. Pemberian hak atas tanah, baik yang dikuasai secara perorangan maupun yang dikuasai secara adat untuk lahanlahan daratan yang tidak dipengaruhi pasang surut air laut lebih mudah diselesaikan, karena sudah diatur oleh Undang-Undang Pokok Agraria. Dan peraturan perundang-undangan lainnya.

Masalah lain yang sangat menonjol adalah daratan-daratan di kawasan pantai tersebut bergerak secara labil dan tak terduga. Pergeseran daratan ini dapat diakibatkan oleh adanya tanah longsor atau adanya tanah timbul akibat sedimentasi seperti yang terjadi di pantai utara Jakarta dan hutan mangrove di Lampung Timur. Dalam usaha memanfaatkan tanah timbul ada perbedaan-perbedaan pendapat. Ada "tanah" yang sudah dimanfaatkan ketika belum lagi berbentuk "tanah", melainkan baru sebagai genangan air yang dangkal. Ada pula sebidang tanah timbul yang sudah dimanfaatkan, ketika sifat tanahnya masih belum pantas lagi diolah untuk menjadi tanah pertanian, karena kadar garam tanahnya masih tinggi.

Dalam pertumbuhan tanah timbul, okupasi lahan oleh masyarakat belum tentu menunggu sampai benar-benar ada wujud "tanah". Begitu tanah itu muncul kemudian dimulai pengolahannya menjadi tanah pertanian yang baik, okupasi masyarakat di atas tanah itu biasanya sudah mantap.

Lahan di kawasan pantai yang tidak dibebani hak milik, dikuasai oleh Negara dan digunakan sesuai peruntukan/fungsinya untuk kemakmuran rakyat. Peralihan status lahan dari lahan Negara menjadi lahan yang dilekati hak yang bukan tanah Negara dapat ditempuh dengan proses permohonan tanah Negara/pemberian hak.

Peraturan yang secara khusus mengatur tanah timbul secara alami memang belum ada, akan tetapi, mungkin dapat digunakan PP No. $8 / 1953$ yang mengatur tentang pengusahaan tanah-tanah Negara, sebelum ada peraturan yang baru..

Selain PP No. 8/ 1953 di atas, kiranya perlu juga diperhatikan UU No. 51/1960, tentang laranan untuk menggunakanmtanah atau muka bumi bagi setiap orang yang tidak memiliki ijin yang syah dari penguasa tanah tersebut. UU No. 1/1960 melarang penggunaan secara liar bagi muka bumi dalam wujud tahapan manapun baik itu masih berwujud tanah yang tergenang air secara berkala, ataupun yang sudah berwujud tanah padat. Dengan UU No. 51/1960 itu, Pemerintah Daerah berwenang mengambil tindakan yang eprlu apabila ada pelanggaranpelanggaran hukum seperti di atas.

Tanah timbul, dalam tahapan yang manapun wujudnya, biasanya ada vegetasinya. Kalau ada yang menebangi pohon-pohon tetapi tidak langsung memanfaatkan tanahnya, orang tersebut dapat juga ditunutt sebagai pelanggar hukum berdasarkan UU No.5/1967 tentang 
Pokok-pokok Kehutanan. Apabila sampai terjadi pencemaran ataupun kerusakan lingkungan hidup, tuntutan dapat juga didasarkan UU No. 4/1982.

Reklamasi pantai yang dilakukan selama ini di Lampung belum menimbulkan masalah dalam hukum pertanahan nasional. Sebab reklamasi tersebut dalam arti yang sebenarnya, yakni menimbun pantai untuk menciptakan daratan baru. Sebagian reklamasi yang dilakukan adalah memunculkan kembali daratan yang terkikis abrasi. Sehingga tanah timbul tersebut tetap sama dengan peta wilayah yang lama sebelum abrasi. Dan juga sebagian lagi merupakan daerah rawa atau ekosistem mangrove yang kebetulan berstatus tanah Negara.

Hal di atas akan berbeda kalau yang direklamasi itu sepenuhnya laut. Sebab hak atas tanah hanya berlaku sampai batas pasir pantai. Karenanya laut tidak dapat dilekati denga hak atas tanah. Pemegang hak atas laut sampai ke batas yang ditentukan oleh "Konvensi Hukum Laut PBB" yang telah diratifikasi Indonesia dengan UU No. 17 tahun 1985 adalah Negara. Jadi seluruh kawasan perairan laut Indonesia dikuasakan Kepada Departemen Perhubungan untuk kepentingan pelayaran.

\section{PENUTUP}

\subsection{Simpulan}

Berdasarkan perkembangan pembangunan wilayah perkotaan dan desa pantai, status kepemilikan lahan pada kawasan pantai dan hutan mangrove sangat beragam, sesuai dengan kondisi biofisik, sosial ekonomi dan tingkat peradaban masyarakat setempat. Ada yang dikuasai perseorangan melalui pemberian tanah Negara baik dengan cara reklamasi, penguasaan tanah timbul, ada yang dikuasai secara adat untuk lahan-lahan daratan yang tidak terpengaruhi pasang surut air laut, dan ada lahan yang dikuasai Negara yaitu daerah pesisir pantai yang kosong.

Bahwa hanya warga Negara Indonesia saja yang boleh mempunyai hak milikatas tanah baik tanah daratan maupun kawasan pantai, hal ini sesuai dengan Pasal 21 ayat (1) Undang-Undang No. 5 Tahun 1960. tentang Peraturan Dasar Pokok-Pokok Agraria, warga Negara asing boleh mempunyai dengan hak pakai atau hak sewa dengan waktu terbatas. Hak Milik yang dipunyai oleh orang asing batal demi hukum melanggar Pasal 26 ayat (2) UUPA.

\subsection{Saran}

Reklamasi pantai akan menjadi trend pengembangan wilayah kota di masa depan, setidak-tidaknya bagi kota-kota besar di Jawa dan Lampung yang berbatasan dengan laut. Tidak saja didorong oleh laju pertumbuhan penduduk, tetapi juga dunia usaha akan lebih memilih reklamasi pantai sebagai upaya mendapatkan lahan yang strategis, mesti dengan investasi yang lebih tinggi.

Sudah waktunya dirumuskan peraturan setingkat Undang-Undang yang mengatur4 kegiatan reklamasi/ pengerukan danau/sungai serta seluruh aspek dan masalah terkait, agar dapat diberikan kepastian hukum, dalam hukum pertanahan yang juga syarat mutlak bagi kesuksesan pembangunan nasional. 


\section{DAFTAR PUSTAKA}

Harsono, Boedi. 2000., Hukum Agraria Indonesia, Sejarah Pembentukan UndangUndang Pokok Agraria. Isi dan Pelaksanaannya. Penerbit Djambatan. Jakarta.

Parlindungan, A.P. 1993., Komentar Atas Undang-Undang Pokok Agraria, Penerbit Mandar Maju. Bandung.

Mertokusumo, Sudikno, 1984. Bunga Rampai Ilmu Hukum, Penerbit Liberty. Yogyakarta.

Rahardjo, Satjipto, 1986. Ilmu Hukum. Penerbit Alumni. Bandung.

Soekanto, Soerjono, 1983. Penegakan Hukum. Penerbit Binacipta. Badan Pembinaan Hukum Nasional Departemen Kehakiman.

Undang-Undang Nomor 27 Tahun 2007 tentang Pengelolaan Wilayah Pesisir Dan PulauPulau Kecil.

Undang-Undang Nomor. 5 Tahun 1960 tentang Peraturan Dasar Pokok-Pokok Agraria.

Undang-Undang Nomor. 5 Tahun 1967 tentang Pokok-Pokok Kehutanan.

Undang-Undang Nomor. 51 Tahun 1960, tentang Larangan untuk Menggunakan tanah atau Muka Bumi Bagi Setiap Orang Yang Tidak Memiliki Ijin yang Sah Dari Penguasa Tanah tersebut. 